\title{
Implementation of conciliation procedures in socio-cultural and legal dimensions
}

\author{
Svetlana Petrovna Kazakova ${ }^{11}$, Olesya Aleksandrovna Kukhareva ${ }^{1}$, Ekaterina Viktorovna \\ Tkachenko $^{1}$, Asiya Nailevna Yusupova ${ }^{1}$ and Dimitri Oleynik ${ }^{2}$ \\ ${ }^{1}$ Saratov State Law Academy, Department of Arbitration, Saratov, Russia \\ ${ }^{2}$ University of Wismar - University of Applied Sciences: Technology, Business and Design, \\ Department of Economic Sciences, Wismar, Germany
}

\begin{abstract}
The study's objective is to develop theoretical provisions revealing the conceptual features of forming and implementing conciliation procedures. The authors pay special attention to the most controversial issues that prevent their dissemination in the Russian Federation. The methodological basis of the study consisted of dialectical analysis, which allowed to evaluate the results of rule-making and law enforcement; the comparative-legal method contributed to an objective assessment of the quality of existing legislation; the systematic method allowed to interpret the categorical apparatus on the example of studying "conciliation procedures"; the method of legal modeling allowed to formulate a model of conciliation procedures, which has a separate, independent place in the legislation of several countries. The result of the work was to draw attention to the meaning of "conciliation procedures" in its empirical and functional aspect and to prove that conciliation procedures, with their objective and subjective justification, are a fundamental category of modern objective law, in which the freedom of choice of subjects of law is not limited to permissive and administrative means, but must be justified by the essence of the dispute being resolved and the final result. The study's novelty is the conclusion that in some cases, the reference to legislation providing for "conciliation procedures" for legal entities is not always consistent and does not reflect its ontological nature. For, conciliation procedures, expressing an example of the permissive rule of Russian legislation with the peculiarities of its legal regulation of certain legal institutions, should be aimed at developing voluntary settlement by the parties to a legal dispute as a special type of social conflict.
\end{abstract}

Keywords: reconciliation of the parties, mediation, negotiations, competence of the authorities

\section{Introduction}

Solving specific socially important tasks, the sectoral legislation of several countries has developed a legal model of conciliation procedures, determined by the mentality and development of society. In this regard, there is no single conceptual and legal approach to

\footnotetext{
${ }^{1}$ Corresponding author: c005er@mail.ru
} 
the definition of "conciliation procedures". This situation does not have a positive impact on their implementation. Modern society in many countries worldwide (Russia, Germany, Italy, Finland, Kazakhstan, Canada) is at a turning point due to changes in several provisions of national legislation establishing conciliation procedures [1,2]. The increase in the normative array regulating various conciliation procedures for the settlement of legal conflicts is due to a number of positive aspects. These include procedural simplicity, focus on the result (resolution) of the conflict, and achieving reconciliation. In this regard, several states have given institutional support to conciliation procedures, which is reflected in the emergence of new alternative ways of dispute resolution and the renewed "efficacy" of those institutions that have long been forgotten and/or have difficulties in practical implementation [3].

In Canada, mediation (private, adjudicative, and judicial) and recourse to mediation are most demanded [4]. Participatory and conciliation procedures have received detailed legislative regulation in France. In Russia, the spread of conciliation procedures is due to procedural savings, reduced material costs of participants in the process, and even the suspension of the statute of limitations [5].

The main conciliation procedure in the civil procedural law of Russia is "negotiations", which are implemented at the will of the parties and external participation (intermediaries). Their peculiarity is that they act in two meanings: as an independent means of settling disputes and as an integral element of other conciliation procedures, such as mediation [6].

In the autumn of 2020, the Ministry of Justice of the Russian Federation developed a Draft Federal Law "On the settlement of disputes involving a mediator (mediation) in the Russian Federation", which does not conceptually differentiate mediation in legal and non-legal, in particular, school conflicts [7]. Thus, when strengthening specific conciliation procedures, including mediation, the legislator does not take into account its essential features, the effective outcome, and the impact on the elimination of the conflict. This position cannot be considered correct.

The Russian legislator's silence on the possibility of including mediation clauses also raises law enforcement issues, such as disputes over the division of jointly acquired property, determining the child's place of residence, the procedure for communicating with the child, labor disputes, and many others. Therefore, changes in the relevant part of the substantive legislation (for example, the family law) will be effective in developing conciliation procedures, but not the only way to improve their effectiveness.

Another conceptual problem is the "emasculation" of the categorical-conceptual apparatus. Some scientists expand the operating range of conciliation procedures, calling them "conciliatory" [8]. The legislation of a number of countries refers to the concepts of "conciliation", "pre-trial" procedures, "pre-trial dispute settlement procedures" [9].

Of course, it is necessary to recognize the right global "steps" of the legislator, aimed at the idea of reconciliation laid down by objective law. However, the implementation of individual conciliation procedures is of particular importance, which should be based on a clear normative and differentiated consolidation, considering the typology of the dispute, the functional purpose of conciliation procedures.

\section{$2 \quad$ Methods}

The study is based on applying two complementary approaches: dialectical analysis allowed evaluating the results of rule-making and judicial law enforcement, and the comparative-legal method of scientific knowledge contributed to an objective assessment of the quality of current legislation in its comparison. The system method allowed interpreting the categorical apparatus on the example of studying "conciliation procedures" and their 
functional component; the method of legal modeling served as a justification for the model of conciliation procedures.

\section{$3 \quad$ Results and discussion}

"Conciliatory procedures" have a long history of their formation and development roots, indicating that society, being formed as an organized community, almost always had conciliatory mechanisms and procedures [10]. However, the options for resolving disagreements between participants in civil legal relations are very diverse and are due to the desire of the legislator to ensure their variability depending on the specific current situation, the subject of disagreements, the reasons and conditions for their occurrence.

With the independence of reconciliation procedures, which have become formally fixed, it is necessary to recognize in some cases their inability to fulfill their essential purpose. There are different reasons for this.

First, these are the rules (limits) of reconciliation, which are well known to the civil process of Russia (Part 2 of Article 39 of the Civil Code of the Russian Federation, Part 2 of Article 138, Part 2.3 of Article 139 of the Commercial Procedure Code of the Russian Federation [11]). The legislator, programming them in advance, must consider the essence of the conflict, its subjects, and the expected result that the parties seek.

Secondly, the tasks of conciliation procedures are aimed at the implementation of their functions.

In modern society, reconciliation procedures perform the following functions:

- external (dual-legal) and internal (mediation) regulation;

- development and adoption of decisions that facilitate the parties to legal disputes in the adoption of compromise agreements;

- regulation of public relations aimed at ending the legal conflict.

However, the purpose of reconciliation procedures is different - resolving the conflict that has arisen [12].

It is necessary to take into account the stage of its emergence: whether the conflict has not turned into a legal dispute, the resolution of which is or should be within the competence of the relevant body of state (judicial) power or an official [13]. In this case, the judicial authorities should explain to the participants of the legal relationship the possibility of resolving the dispute through a particular conciliation procedure with the disclosure of its attractive properties. From a dialectological point of view, the latter will contribute to the prevention of subsequent offenses, their prevention through self-control, and the establishment of friendly relations. Therefore, administrative regulations of officials and the regulatory framework governing the activities of the enforcement courts must provide legal information to parties to a conflict/dispute. The procedural civil form should include requirements in the form of a legal prescription for enforcement judges to explain the appropriate conciliation procedure in each case submitted to the court.

It is necessary to consider categories of disputes to be resolved through mediation, especially in tourism [14]. Others, for example, sports, school - by other conciliatory procedures. These include negotiations between the parties that precede the involvement of third parties. Their effectiveness is due to their availability, gratuitousness, and ability to model the actual situation. However, it is impossible to achieve the desired result without the support of the state, which must stimulate the parties at the legislative level both financially (by reducing the size of the state fee for complying with the mediation procedure before going to court) and organizationally. In particular, implement preliminary dispute resolution mechanisms, such as negotiations.

In a number of case categories where there is a power element, in particular, in cases from administrative and other public legal relations, the inequality of the dispute subjects 
does not allow the use of conciliation procedures in full functional scope, which are in contact with the purpose and objectives of conciliation procedures [15].

The reason that hinders reconciliation procedures is the lack of proper awareness of citizens about the existence of an alternative to judicial proceedings and, as a result, the lack of confidence of citizens in reconciliation procedures.

Ignorance is the key to the ineffectiveness of many conciliation procedures, despite their obvious relevance in the mechanism of legal regulation. The reasons lie not in the lack of scientific concepts or training programs, activities aimed at improving legal literacy, certainly contributing to the development of conciliation procedures, but in the mechanism of their implementation by law enforcers. This requires a formal attitude and a live dialogue of the official [16], especially when working with minors, which reveals the very conceptual idea and the means of implementation. Therefore, it is necessary to include the conditions for encouraging the parties to use conciliation procedures in the legal regulations. At the stage of legal modeling, it is necessary to consider:

- $\quad$ the nature of the claims and the subject matter of the conflict;

- $\quad$ the subjects of the conflict (dispute), especially minors and those whose interests they can/should uphold;

- the factual circumstances that are likely to form the basis of the objections;

- result.

Third, the tasks of reconciliation procedures include "programming" actions aimed at achieving the goal. To do this, the legislator must consider the essence of the dispute [17], the parties' capabilities, and the motivations of the latter. An example of the parties' incentive may be legal obstacles that make it impossible to consider the case in court. These include, for example, the institution of returning the statement of claim before meeting the requirements of the law on compliance with the pre-trial procedure for dispute settlement, the availability of justice in state courts due to the low material cost of the state fee.

\section{Conclusion}

The results of scientific research and legislative regulation demonstrate that conciliation procedures, which form a conceptual model of reconciliation that differs from the essence of the resolved dispute (conflict) in its empirical and functional aspects, are the fundamental category. In this regard, it is essential to consider the purpose and objectives of conciliation procedures resolved without considering the merits of the case in court. The freedom of choice of the law subjects must be justified by the nature of the dispute resolved and the final result. In some cases, the reference to legislation providing for conciliation procedures for legal entities is not always consistent and does not reflect their ontological nature. Conciliation procedures, expressing an example of the permissive rule of legislation with the peculiarities of its legal regulation of certain legal institutions, should be aimed at developing voluntary settlement by the parties to a legal dispute as a special type of social conflict.

\section{References}

1. K. Ervasti, Utrecht Law Rev. 14(3), 19-30 (2019). http://doi.org/10.18352/ulr.469

2. M. Schweizer, Beweiswurdigung und Beweismass: Rationalitat und Intution [Proof appreciation and measure of proof: Rationality und Intution] (Mohr Siebeck, 2015). https://doi.org/10.1628/978-3-16-153759-2

3. S. Asanova, Primiritelnye protsedury v grazhdanskom sudoproizvodstve Respubliki Kazakhstan [Conciliatory procedures in civil proceedings of the Republic of 
Kazakhstan], in V.P. Ocheredko, A.N. Kuzbagarov, S.Yu. Katukova (eds.), Conciliatory procedures in civil law and legal proceedings. Collection of materials of the International Scientific-Practical Conference of April 26-27, 2019, Saint-Petersburg, part 2 (Asterion, Saint Petersburg, 2019)

4. R.M. Shakuryanov, Mediatsiya v grazhdanskom protsesse Kanady [Mediation in the civil process of Canada], in V.P. Ocheredko, A.N. Kuzbagarov, S.Yu. Katukova (eds.), Conciliatory procedures in civil law and judicial proceedings. Collection of materials of the International Scientific-Practical Conference of April 26-27, 2019, Saint-Petersburg, part 2 (Asterion, Saint Petersburg, 2019)

5. M.A. Fokina, Bul. Civil Procedure 10(2), 121 (2020)

6. E.I. Nosyreva, D.G. Filchenko, Bul. Civil Procedure 10(2), 143 (2015)

7. Pravovaya pozitsiya FPA RF o Proekte federalnogo zakona "Ob uregulirovanii sporov s uchastiem posrednika (mediatsii) v Rossiiskoi Federatsii" ot 08.10.2020 [Legal position of the Federal Chamber of Lawyers of the Russian Federation on the Draft Federal Law "On the settlement of disputes with the participation of a mediator (mediation) in the Russian Federation" from 08.10.2020]. Accessed on: June 26, 2021. [Online]. Available: https:/fparf.ru/documents/fpa-rf/the-legal-position-of-fpa/

8. S.B. Serenko, Soglasitelnye protsedury pri prinyatii nasledstva [Conciliation procedures at the acceptance of inheritance], in V.P. Ocheredko, A.N. Kuzbagarov, S.Yu. Katukova (eds.), Conciliation procedures in civil law and legal proceedings. Collection of materials of the International Scientific-Practical Conference of April 26-27, 2019, Saint-Petersburg, part 2 (Asterion, Saint Petersburg, 2019

9. G.K. Bakytzhanova, Bul. Civil Procedure 10(2), 187 (2020)

10. A. Nylund, L. Adrian, K. Ervasti (eds.), Mediation Research. (Springer, 2018)

11. Arbitrazhnyi protsessualnyi kodeks Rossiiskoi Federatsii ot 24.07.2002 № 96-FZ (v red. 428-FZ ot 08.12.2020), b Sobr. zak-va RF. 2002. № 30. St. 3012; 2020. Chast 3. № 50. St. 8073 [Arbitration Procedural Code of the Russian Federation No. 96-FZ of 24.07.2002 (as amended by 428-FZ of 08.12.2020), Collection of Laws of the Russian Federation. 2002. No. 30. Art. 3012; 2020. Part 3. No. 50. Art. 8073] Accessed on: June 26, 2021. [Online]. Available: https://www.szrf.ru/szrf/index.php?md=0

12. O.A. Sukhorukova, Effektivnost grazhdanskogo sudoproizvodstva. Kommunikativnyi aspekt [The effectiveness of civil proceedings. The communicative aspect] (Uright, Moscow, 2019)

13. O. Nikolaychenko, V.V. Nikolaychenko, Stud. Comput. Intellig. 826, 382 (2019). https://doi.org/10.1007/978-3-030-13397-9_44

14. O.V. Isaenkova, A.S. Kuskov, N.V. Sirik, S.M. Vasina, IOP Conf. Ser.: Earth Environ. Sci. 204, 012013 (2018). https:// 204012013 doi.org/10.1088/1755-1315/204/1/012013

15. O.N. Shemeneva, Rol protsessualnykh soglashenii v grazhdanskom sudoproizvodstve [The role of procedural agreements in civil proceedings]. Abstract of Doctoral thesis in Legal Science (Voronezh, 2017)

16. A.I. Taranenko, G. Panasenko, J. Sib. Fed. Univ. Hum. Soc. Sci. 10, 214-218 (2017). https://doi.org/10.17516/1997-1370-0022

17. L.G. Shcherbakova, Bul. Tomsk State Univ. 403, 172-188 (2016) https://doi.org/10.17223/15617793/403/28 